University of Nebraska - Lincoln

DigitalCommons@University of Nebraska - Lincoln

Papers in the Earth and Atmospheric Sciences

Earth and Atmospheric Sciences, Department

$11-1912$

\title{
NOTICE OF NEWLY DISCOVERED EURYPTERIDS IN NEBRASKA
}

Erwin Hinckley Barbour

University of Nebraska-Lincoln

Follow this and additional works at: https://digitalcommons.unl.edu/geosciencefacpub

Part of the Earth Sciences Commons

Barbour, Erwin Hinckley, "NOTICE OF NEWLY DISCOVERED EURYPTERIDS IN NEBRASKA" (1912). Papers in the Earth and Atmospheric Sciences. 356.

https://digitalcommons.unl.edu/geosciencefacpub/356

This Article is brought to you for free and open access by the Earth and Atmospheric Sciences, Department of at DigitalCommons@University of Nebraska - Lincoln. It has been accepted for inclusion in Papers in the Earth and Atmospheric Sciences by an authorized administrator of DigitalCommons@University of Nebraska - Lincoln. 
NOTICE OF NEWLY DISCOVERED EURYPTERIDS IN NEBRASKA

A BED of Eurypterids has just been discovered by the Nebraska Geological Survey in the Carboniferous shales of southeastern $\mathrm{Ne}$ braska, and thus a new locality is added to the list for the United States. Such localities are somewhat rare, and notice of any and every new one must be acceptable.

The Carboniferous outcrops are confined to some eight or ten counties in the extreme southeastern corner of the state, and though covered heavily by glacial clays, bold exposures occur in proximity to the bolder streams, especially the Missouri River. About a mile south of Peru, on the Missouri River front, the bluffs are limestones interbedded with thin layers of shale. But within a few hundred feet the shale thickens until the limestone pinches out altogether, and within as many feet the shale becomes increasingly arenaceous until it merges into a bed of massive cross-bedded sandstone. Within a mile this order is symmetrically reversed.

About one and a half miles south of Peru and immediately at the side of the Burlington track, and some thirty feet above the river, there occurs in this massive sandrock an irregular bed about a foot thick comprising alternating bands of sand and thin layers of compact slate-colored shale. These shale seams are seldom thicker than a quarter of an inch. They cleave readily and expose surfaces covered by innumerable leaves, stems, and their fragments. Neuropteris pinnules, and stems of Calamites are abundant.

Associated with these are the newly discovered Eurypterids. From observation in the field they seem to be adults, and yet they are diminutive, measuring but $1 \frac{1}{2}$ inches (38 mm.) in length. They appear to be fairly 
plentiful, for seven individuals were found on a space less than one yard square. They are well preserved and, in the case of one at least, the anatomy can be worked out in detail even to the joints of the appendages.

Apparently there are three distinct forms, which probably represent as many species, and at least two genera. If study substantiates the belief that these are new, they will be described at an early date.

One is noticeably scorpioid in outline, due to a rapid constriction beginning at the ninth abdominal segment. At the sixth segment the abdomen measures $10 \mathrm{~mm}$. across, while at the ninth it measures but half as much. The cephalothorax measures $5 \mathrm{~mm}$. in length, the abdomen to the tip of the telson $23 \mathrm{~mm}$., and the telson alone $13 \mathrm{~mm}$. The segments seem to be destitute of ornamentations. Five appendages are exposed on one side and are distinct even to the individual joints, none of which are chelate, and there is no paddle.

Another form shows an abdomen expanding slightly to the fourth segment and then contracting and graduating insensibly into the pointed telson. The eyes and markings of the cephalothorax differ from the first-mentioned form. The abdominal segments are plainly ornamented by numerous and relatively large rounded prominences.

In a third form, noticeably vermiform, the slender abdomen tapers from the head shield to the telson. The cephalothorax is ornamented by two long and relatively broad genal spines which sweep backward to the telson. Ornamentation seems to be wanting on the segments. One distinct paddle is exposed. This small collection of seven Eurypterids was made under difficulties. Later in the season an unstable overhanging block of sandstone will be blasted away and at once several square yards of Eurypterid shales can be safely exposed. The expectation is that a considerable collection will be secured, which when properly studied will be figured and described in a forthcoming number of the Nebraska Geological Survey.

This set of Eurypterids belongs to the collections of Hon. Charles H. Morrill, who for so many years has been a liberal patron of geological and paleontological research in $\mathrm{Ne}$ braska.

The University of Nebraska, Erwin H. Barbour 